\title{
Statistical analysis of water quality parameters in the basin of the Nišava River (Serbia) in the period 2009-2018
}

LJILJANA STRIČEVIĆ ${ }^{1}$, MILA PAVLOVIĆ ${ }^{2}$, IVAN FILIPOVIĆ ${ }^{1}$, ALEKSANDAR RADIVOJEVIĆ ${ }^{1}$, NATAŠA MARTIĆ BURSAĆ ${ }^{1}$, MILENA GOCIĆ ${ }^{1}$

1 University of Niš, Faculty of Sciences and Mathematics, Department of geography, Niš, Serbia; e-mail: ljiljana.s.stricevic@gmail.com, ifilipovic@pmf.ni.ac.rs, a.radivojevic@yahoo.com, natasamarticbursac@gmail.com,milena.j.gocic@gmail.com

${ }^{2}$ University of Belgrade, Faculty of Geography, Serbia; e-mail: mila.pavlovic2@gmail.com

ABSTRACT This paper analyzes water quality from four hydrological stations in the Nišava river basin from 2009-2018 based on the following parameters: $\mathrm{pH}$, conductivity, $\mathrm{O}_{2}$ saturation, $\mathrm{BOD}_{5}$, suspended solids, total oxidized nitrogen, phosphates, turbidity and coliform bacteria. Authors have applied WQI (water quality index) as the most reliable indicator of the watercourses pollution for setting of surface water flow quality. Statistical analysis of variance (ANOVA) using t-test inferential statistical analysis and post-hoc Tukey test were applied to evaluate statistically significant differences between specific data groups. The results show that bad water quality was registered on all the profiles on an annual basis (WQI $=65-71$ ). The river water $\mathrm{pH}$ decreases downstream, while values of $\mathrm{BOD}_{5}$, suspended solids, turbidity, TON, phosphates and coliform bacteria gradually increase. The waters of the Nišava at the station Niš belong to the third class of waters and they are mostly loaded with organic matter originating from waste sewage and industrial waters of both urban and rural areas.

KEY WORDS Nišava River - Serbia - WQI - water pollution

STRIČEVIĆ, L., PAVLOVIĆ, M., FILIPOVIĆ, I., RADIVOJEVIĆ, A., BURSAĆ, N.M., GOCIĆ, M. (2021): Statistical analysis of water quality parameters in the basin of the Nišava River (Serbia) in the period 2009-2018. Geografie, 126, 1, 55-73.

https://doi.org/10.37040/geografie2021126010055

Received July 2020, accepted January 2021.

CC Česká geografická společnost, z. s., 2021 


\section{Introduction}

Protection and usage of waters as a renewable resource is an issue relevant to all segments of society. Due to uneven temporal and spatial water distributionconditioned by global climate changes and other anthropogenic effects-roughly $80 \%$ of the world's population is at high risk of water scarcity or sanitary defective water (Filipović, Stričević 2017). Water quality thus requires a responsible public response to control and distribute the resource in the most responsible and economic means for the society, including establishing the main causes and factors of degradation and implementing adequate measures for rehabilitation and revitalization (Vorosmartty et al. 2010). One of the most important planning documents in the field of water resources management is the European Union Water Framework Directive of 2000 (Directive 2000/60/EC), the goal of which is to ensure good hydrological, chemical and ecological status of waters, according to the principles of sustainable management, with usage that does not endanger the environment, (Marković 2011). Proper monitoring is necessary to both achieve satisfactory surface water quality and contribute to sound water management policies (Matijević et al. 2014). The quality of surface water bodies is a very sensitive environmental issue. Surface water quality is determined by natural processes-climatic, hydrological and geological (air temperature, precipitation, mean water level, flow variation, soil erosion) - as well as human activities such as urbanization, industry, mining, metallurgy, agriculture and increased consumption of freshwater resources (Dragićević et al. 2010, Babić et al. 2019).

The surface water quality in a region can be affected by both point and nonpoint sources of pollution (Huang, Xiang 2015). Point source pollution occurs from a single identifiable source such as effluents from industries and wastewater treatment plants, whereas nonpoint sources include runoff associated with a particular land use pattern such as urban (sewage overflows), agriculture (e.g., fertilizers, pesticides), or forestry land uses (Simeonova et al. 2013, Bu et al. 2013). Entry of these sources into water can represent the improper discharge of toxic chemicals and pathogenic microorganisms; therefore, water quality monitoring and sanitary risk identification are essential for protecting the population from waterborne diseases and developing appropriate preventive measures (Bhat et al. 2014, Vadde et al. 2018).

The study of the quality and pollution of watercourses in the world is usually based on the application of various mathematical and statistical methods (Pantelić et al. 2012; Priya, Das, Vareethiah 2015; Leščešen et al. 2015). In recent years, the analyses of watercourse quality based on mathematical indexes have become increasingly common. Authors most frequently refer to the WQI (Water Quality Index) as a simple indicator of watersheds pollution (Parmar, Parmar 2010; Nagel 2001) or to a modified index, such as the Oregon Water Quality Index, as a tool for 
evaluating water quality management effectiveness (Yotova et al. 2020). The WQI was used as the indicator of the surface water quality in the rivers of Bulgaria (Yotova et al. 2020), Albania (Damo, Icka 2013), Romania (Dunca 2018), Iran (Fathi, Ahmadmahmoodi, Zare Bidaki 2018), Malaysia (Naubi et al. 2016), as well as for the assessment of the water quality and pollution in the rivers of Serbia: Dunav (Josimov Dundjerski et al. 2016, Takić et al. 2012), Sava (Bjelajac et al. 2013), Tisa (Leščešen et al. 2014, Babić et al. 2019), Timok (Milijašević Joksimović, Gavrilović, Obradović Lović 2018), Drina (Leščešen et al. 2013).

Numerous researchers have studied the problem of the water quality and pollution of the Nišava River and its tributaries within the scope of the analysis of environmental state or the watercourse quality (Gocić, Trajković 2013; Leščešen, Pavić, Dolinaj 2018) and the pollution caused by wastewater from human settlements (Veljković 2013). Over the past several decades, the rivers in the Nišava basin have become increasingly worse due to discharges from communal wastewater from the populated areas (Dimitrovgrad, Pirot, Bela Palanka and Niš) and Bulgaria (Dragoman, Trn, Godeč). The wastewater is discharged into water courses without purifying or in an uncontrolled manner, causing degradation and endangering the living world in the water courses. These waters are mostly loaded with organic compounds. Apart from communal waters, the greatest danger to water quality in the Nišava basin is the disposal of solid waste and formation of illegal dumps very close to water facilities.

This paper determines WQI from four hydrological stations in the Nišava river basin from 2009-2018, together with statistical analysis of nine water quality parameters reflecting water quality and pollution levels. These results can form a basis for further, more detailed analysis of water quality and pollution in the Nišava basin and to establish guidelines and activities for future protection initiatives; inform the public on water quality, and to establish guidelines and recommendations for water use.

\section{Study Area}

The Nišava River basin is located in south-eastern Serbia (Fig. 1). The spring of the Nišava River is located in Bulgaria, the length of its course is $202 \mathrm{~km}$ and it is oriented SE-NW (Gavrilović, Dukić 2002). Its source is close to the Serbian border, on the Bulgarian side of Stara Planina Mountain. It enters Serbia after $51 \mathrm{~km}$ of flow through Bulgarian territory without receiving any major tributaries. The river flows generally to the west for the remaining $151 \mathrm{~km}$, it passes by the towns of Dimitrovgrad, Pirot, Bela Palanka, and Niš after which the Nišava River flows into the Južna Morava River. The surface area of the river basin is $4,052.7 \mathrm{~km}^{2}$ in total, $2.987 \mathrm{~km}^{2}$ belonging to Serbia (Djokić 2015). It is the largest tributary of 

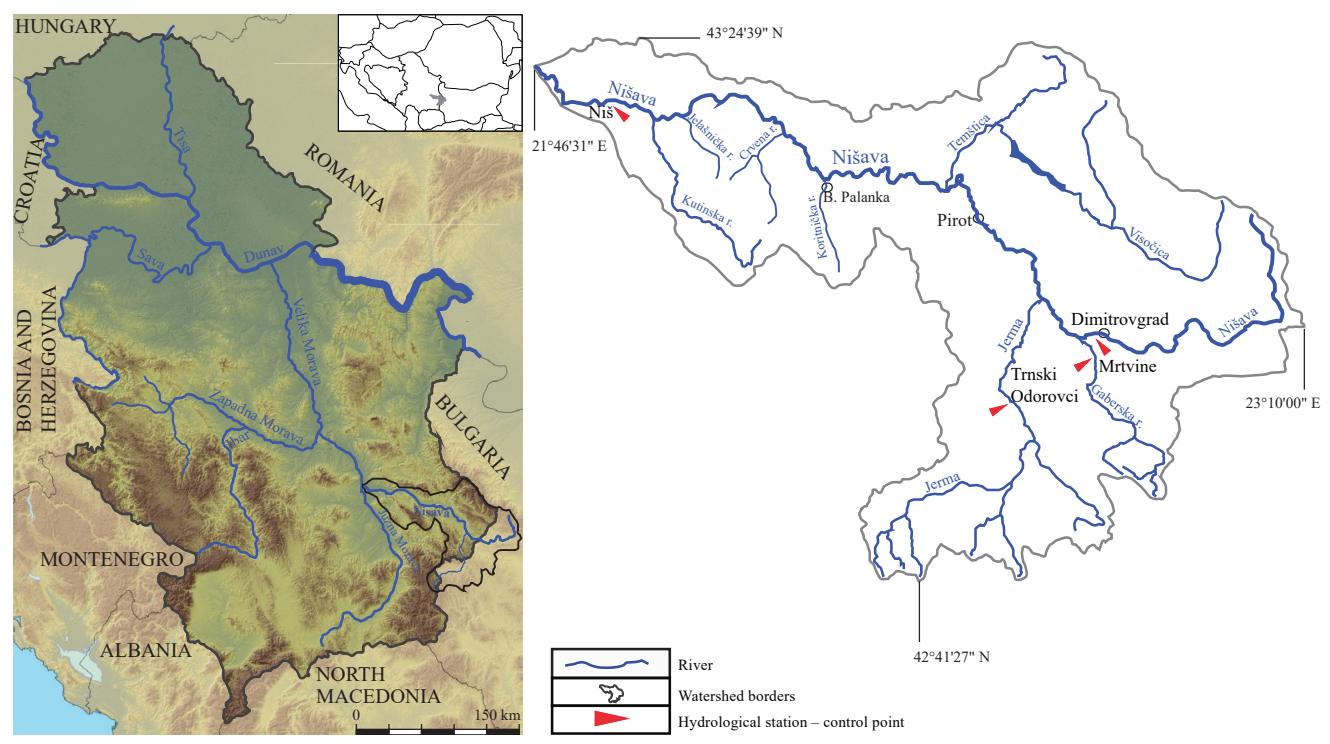

Fig. 1 - Geographical location of the research area and location of sampling sites CP1-CP4 in the Nišava River basin. Source: according Geographical atlas (Geozavod 2002) and Topographical maps 1:200,000 (Military Geographical Institute Belgrade).

the Južna Morava River, both in length and in discharge $\left(28.4 \mathrm{~m}^{3} / \mathrm{s}\right)$. It has many tributaries, the biggest are the Temštica from the right, and the Gaberska reka, the Jerma River, the Koritnička reka and the Kutinska reka from the left.

The elevation ranges from $177 \mathrm{~m}$ to $2,170 \mathrm{~m}$ above sea level. The average altitude of the basin is $813 \mathrm{~m} .18 .6 \%$ of the basin area is located up to an altitude of $500 \mathrm{~m}$, $55.5 \%$ between $500-1,000 \mathrm{~m}$ and $25.9 \%$ of the basin area is above $1,000 \mathrm{~m}$. The basin is located in an area under the influence of a moderate continental climate. The average annual air temperature in the basin is $8.3^{\circ} \mathrm{C}$. The average annual precipitation in the basin is $782 \mathrm{~mm}$. Out of the total precipitation amount, $222 \mathrm{~mm}$ interflows, while the rest of $560 \mathrm{~mm}$ evaporates. The share of precipitation which go into the discharge is $28 \%$, that is, runoff quotient is 0.28 . The highest value of the runoff quotient is recorded on most stations during winter $(0.44)$, while the lowest is recorded during summer (0.14).

According to Corine Land Cover database (2012) agricultural areas comprise $32 \%$ of the Nišava basin surface. These areas are mostly located at lower altitudes, near rivers and rural settlements. Meadows and pastures occupy about $3 \%$ of the surface, while forests and semi-forest areas cover $64 \%$ of the catchment area.

According to a census in 2011 (Statistical Office of the Republic of Serbia - SORS 2011), there are 342,720 inhabitants in total on the territory of the Nišava River basin located in 4 urban and 241 rural settlements. 


\section{Data and Methods}

The database of the Serbian Environmental Protection Agency (SEPA) for the period 2009-2018 was used to present the existing state of water quality of the Nišava River basin. Parameters of physical, chemical and microbiological water quality were measured on the four control points (approximately once a month): Niš (CP1) and Dimitrovgrad (CP2) on the Nišava River, Mrtvine (CP3) on the Gaberska reka and Trnski Odorovci (CP4) on the Jerma River (Fig. 1). The data obtained at each measurement station were averaged using the annual arithmetic average mean. We thereby obtained a series of 12 values per year for four hydrological stations for the 10year period (2009-2018).

Water quality was analyzed based on the following parameters: $\mathrm{pH}$, conductivity, $\mathrm{O}_{2}$ saturation, $\mathrm{BOD}_{5}$, suspended solids, total oxidized nitrogen (TON), phosphates, turbidity and coliform bacteria. Based on these data, the state of surface water quality in the Nišava basin is presented in accordance with the applied water quality standards of the Republic of Serbia.

Presented results were obtained according to several different statistical analyses applied in similar researches: descriptive statistical analysis, t-test for independent samples (Chougule, Sonaje 2014) and one-way analysis of variance (ANOVA; Kundu 2012; Priya, Das, Vareethiah 2016). Post-hoc Tukey test was applied for definition of difference significance between certain groups.

Descriptive statistical analysis was applied for definition of parameters mean values according to profiles and time periods.

One-way analysis of variance is a statistical procedure that ensures difference testing between several arithmetic means. One-way ANOVA enables using the F-Test to determine whether, within compared data sets, there is at least one that significantly deviates from the mean of the other compared data sets (Mutavdžić, Nikolić Djorić 2018). The F-Test determines the variance of each of the analyzed groups and defining Sum-of-Squares within groups $\left(\mathrm{SS}_{\mathrm{w}}\right)$, as well as the variance between the analyzed groups and defining Sum-of-Squares between groups $\left(\mathrm{SS}_{\mathrm{B}}\right)$. Based on the parameters Total Sum-of-Squares $\left(\mathrm{SS}_{\mathrm{T}}\right)$ is defined as:

$$
\begin{aligned}
& \mathrm{SS}_{\mathrm{B}}=\sum_{\mathrm{k}_{\mathrm{i}=1}} \mathrm{n}_{\mathrm{i}}\left(\mathrm{x}_{\mathrm{i}}-\mathrm{x}\right)^{2} \text {, where: } \\
& \mathrm{n}_{\mathrm{i}}=\text { number of subjects in the } \mathrm{i} \text {-th group. } \\
& \mathrm{SS}_{\mathrm{W}}=\sum_{\mathrm{k}_{\mathrm{i}=1}}\left(\mathrm{n}_{\mathrm{i}}-1\right) \mathrm{S}_{\mathrm{i}}^{2} \text {, where: } \\
& \mathrm{S}_{\mathrm{i}}=\text { standard deviation of the } \mathrm{i} \text {-th group } \\
& \mathrm{SS}_{\mathrm{T}}=\mathrm{SS}_{\mathrm{B}}+\mathrm{SS}_{\mathrm{W}}
\end{aligned}
$$


However, definition of SS within and between the groups does not enable us to conclude if variability is greater within or between the groups, since square sum amount depends upon the number of results. Therefore, variance is taken as a measure of variability. The value of variance is obtained when each of the obtained SS values is divided by the corresponding values of degrees of freedom $\mathrm{DF}$. The obtained value is named the middle square (MS). Degrees of freedom for $\mathrm{SS}_{\mathrm{w}}$ are obtained by subtracting the number $1(\mathrm{k}-1)$ from the total number of analyzed groups, while the degree of freedom for $\mathrm{SS}_{\mathbf{B}}$ is calculated by subtracting the number of groups $(\mathrm{N}-\mathrm{k})$ from the total number of samples. Based on the obtained MS values, F-statistics is calculated as a ratio of $\mathrm{MS}_{\mathbf{B}}$ (mean square between groups) and $\mathrm{MS}_{\mathrm{w}}$ (mean square within groups):

$$
\begin{aligned}
& \mathrm{MS}_{\mathrm{B}}=\frac{\mathrm{SS}_{\mathrm{B}}}{(\mathrm{k}-1)} \\
& \mathrm{MS}_{\mathrm{W}}=\frac{\mathrm{SS_{ \textrm {w } }}}{(\mathrm{N}-\mathrm{k})} \\
& \mathrm{F}=\frac{\mathrm{MS}_{\mathrm{B}}}{M S_{\mathrm{W}}}
\end{aligned}
$$

The derived F-Value is compared to the values in the table of critical values for $F$ distribution, for the defined degrees of freedom, as well as significance threshold $p=0.01$. If the obtained F-Value is equal to or greater than the critical value for the given degrees of freedom, we can conclude that the obtained result is statistically significant for the defined significance threshold.

Based on the results of the F-Test, if it shows a certain statistical significance, nothing can be concluded about the mutual relations of the compared sets (i.e. which differences in their means are statistically significant, and which are not). To characterize the differences between the sets more closely, it is necessary to apply a post-hoc test; in this paper we have applied Tukey post-hoc test.

The t-test for independent samples is used for comparison of mean values of results and definition of statistical significance of their differences (Macura 2019). A larger $t$-value shows that the difference between group means is greater than the pooled standard error, indicating a more significant difference between the groups. A risk possibility level of $5 \%$ and $1 \%$ was taken into account in the process of definition of statistical significance of obtained results, whereas the limit is based on freedom degrees interpreted according to t-tables. At examined samples at a significance level of $5 \%(\mathrm{p}<0.05)$ or less, the t value must be at least 1.97, whereas at a significance level of $1 \%(\mathrm{p}<0.01)$, $t$ must be at least 2.58 .

Apart from the above-mentioned analyses, the authors used the qualification system to describe surface water quality using the Serbian Water Quality Index (SWQI) method (Stričević et al. 2015; Leščešen, Pavić, Dolinaj 2018; Babić et al. 
2019). This method is based upon the fact that ten chosen parameters (oxygen saturation, $\mathrm{BOD}_{5}$, ammonium, $\mathrm{pH}$ value, TON, orthophosphates, suspended solids, temperature, conductivity and coliform bacteria) with their quality ( $\left.\mathrm{q}_{\mathrm{i}}\right)$ represent features of surface water reducing them at one index number. The influence of each of the ten chosen parameters on general water quality is not the same, so that each of them was assigned the weight $\left(\mathrm{w}_{\mathrm{i}}\right)$ and the score of points according to their contribution to water quality endangering. The result $\left(\mathrm{q}_{\mathrm{i}} \cdot \mathrm{w}_{\mathrm{i}}\right)$ gives the index 100 , as an ideal summation of weights of all parameters (Oregon Water Quality Index Summary Report 1996-2005). Index points from 0 to 100 will be assigned to particular waterbody according to the points assigned to particular parameters (Veljković, Jovičić 2007; Petz 2007; Leščešen et al. 2014). According to WQI category, the values for WQI descriptive quality indicator are defined as follows: very bad - 0-38; bad - 39-71; good - 72-83; very good - 84-89 and excellent - 90-100. To interpret the obtained results and assess the quality of watercourses, we used the method of comparing quality indicators according to the classification of waters in Serbia as well as the Water Quality Index method. The quality of surface water which corresponds to I class WQI method assigns 84-85 points, II class 72-78 points, III class 48-63 points, and IV class 37-38 points (Veljković 2006).

\section{Results}

Mean values for nine parameters $\left(\mathrm{pH}\right.$, conductivity, $\mathrm{O}_{2}$ saturation, $\mathrm{BOD}_{5}$, suspended solids, TON, phosphates, turbidity and coliform bacteria) for the observed ten-year period (2009-2018), as well as the results of ANOVA test for all the four Control Points (Niš - CP1, Dimitrovgrad - CP2, Mrtvine - CP3 and Trnski Odorovci CP4) are presented in Table 1. ANOVA was used to define if there is statistically significant correlation between dependent variables (observed parameters) and independent variable (CP). Post-hoc Tukey test was applied to define significantly different variables. Differences between values of observed parameters according to warm or cold period of year for ten year long period are presented in Table 2 according to t-test. Monthly mean values of these parameters were used to calculate SWQI. According to water regulations in Serbia, all surface water bodies in this country are divided into four classes. Limit values of average concentrations of analyzed parameters are defined for each of these classes by the Regulation on Limit Values of Pollutants in Surface and Underground Waters of the Republic of Serbia (Official gazette of RS, No. 50/2012).

Statistical analysis of $\mathrm{pH}$ for all control points indicates a significant statistical difference at significance level $\mathrm{p}<0.01(\mathrm{~F}=8.875, \mathrm{p}=0.0002)$. The highest $\mathrm{pH}$ values were registered at CP4 on the Jerma River (8.31), while the lowest were registered at CP1 on the Nišava River (7.99). The results of post-hoc test confirm 
Table 1 - Mean Values of chemical parameters which show water quality in the Nišava River Basin and ANOVA Results

\begin{tabular}{lccccrl}
\hline Parameters & $\begin{array}{c}\text { Niš } \\
(\mathrm{CP} 1)\end{array}$ & $\begin{array}{c}\text { Dimitrovgrad } \\
(\mathrm{CP} 2)\end{array}$ & $\begin{array}{c}\text { Mrtvine } \\
(\mathrm{CP} 3)\end{array}$ & $\begin{array}{c}\text { Trnski } \\
\text { Odorovci } \\
(\mathrm{CP} 4)\end{array}$ & $\mathrm{F}$ & $\mathrm{P}$ \\
\hline $\mathrm{pH}$ & 7.9 & 8.20 & 8.27 & 8.31 & 8.875 & $0.0002^{*}$ \\
Conductivity $(\mu \mathrm{S} / \mathrm{cm})$ & 431.9 & 466.3 & 603.7 & 359.3 & 115.689 & $0.000^{*}$ \\
$\mathrm{O}_{2}$ saturation $(\%)$ & 84.6 & 101.6 & 98.2 & 102.9 & 11.929 & $0.0000^{*}$ \\
$\mathrm{BOD}_{5}\left(\mathrm{mg} \mathrm{O}_{2} / \mathrm{l}\right)$ & 3.34 & 2.13 & 2.96 & 1.72 & 65.263 & $0.000^{*}$ \\
Suspended solids $(\mathrm{mg} / \mathrm{l})$ & 25.0 & 12.7 & 13.2 & 18.9 & 2.529 & 0.0750 \\
TON $(\mathrm{mg} / \mathrm{l})$ & 1.30 & 0.73 & 0.84 & 0.61 & 8.566 & $0.0003^{*}$ \\
Amount of coliform bacteria (CFU/l) & 76,195 & 10,979 & 13,901 & 5,240 & 3.761 & 0.0200 \\
Phosphates & 0.281 & 0.058 & 0.072 & 0.074 & 23.508 & $0.0000^{*}$ \\
Turbidity (NTU) & 38.6 & 10.7 & 13.8 & 22.9 & 4.316 & 0.0120 \\
\hline
\end{tabular}

Note: ${ }^{*} \mathrm{p}<0.01 ; \mathrm{F}>4.46$

statistically significant differences between the values of $\mathrm{pH}$, whereas the highest differences are those between CP1 and CP3, as well as CP1 and CP4. Based on the limit $\mathrm{pH}$ values of surface waters defined in Serbia $(\mathrm{pH}=6.5-8.5)$, we can conclude that in all the analyzed control points $\mathrm{pH}$ parameter shows that water quality belongs to I class. Out of the total analyzed 120 monthly $\mathrm{pH}$ parameters, 17 had values greater than 8.5. During these months the waters belonged to the quality Class III.

Measured values of conductivity for the research period show significant differences at significance level $\mathrm{p}<0.01(\mathrm{~F}=115.689, \mathrm{p}=0.0000)$. The highest values were measured at the CP3 $(603.7 \mu \mathrm{S} / \mathrm{cm})$, and the lowest value at CP4 $(359.3 \mu \mathrm{S} / \mathrm{cm})$. This is confirmed with the post-hoc test, which shows statistically significant differences between these two stations. The increase in the value of conductivity at the CP3 station is influenced by the increased concentration of ions in water solution, formed by dissolving shales, sand, marl and limestone as dominant rocks that participate in the structure of the Gaberska River basin. Electrical conductivity and suspended solids are highly dependent on hydrological conditions, such as flow rate and water level, or current seasonal conditions, such as rainy and dry periods (Babić et al. 2019). Some of these factors affect lower values of conductivity at other control points in the Nišava River basin (see Table 1).

The highest value of water oxygen saturation was registered at CP4 (102.9\%), while the lowest was registered at CP1 (84.6\%). Statistical analysis of oxygen saturation for all the four analyzed stations shows significant differences at significance level $\mathrm{p}<0.01(\mathrm{~F}=11.929, \mathrm{p}=0.000)$. According to the Tukey test, a significant statistical difference in the oxygen saturation was recorded between CP1 and all the other control points in the basin. Based on the stated oxygen values, 
according to the defined limit values of this parameter in Serbia, the waters of the Nišava River in Niš can be classified as Class II (70-90\%), while the water at other stations would be Class I (90-110\%). Out of the total 120 monthly $\mathrm{O}_{2}$ parameters, 61 had values less than 90 (Class II), of which 42 values were recorded on CP1. The low oxygen saturation at the lowest downstream station on the Nišava is likely caused by the discharge of high volumes of untreated sewage water from the city of Niš and surrounding areas.

$\mathrm{BOD}_{5}$ indicates the level of organic pollution. The highest $\mathrm{BOD}_{5}$ was registered at $\mathrm{CP1}\left(3.34 \mathrm{mg} \mathrm{O}_{2} / \mathrm{l}\right)$ and the lowest at $\mathrm{CP} 4(1.72 \mathrm{mg} \mathrm{O} / \mathrm{l})$ The analysis confirmed a statistically significant difference between these parameters on all four profiles $(F=65.263, p=0.000)$. The results of the Tukey test do not show a statistically significant difference only between the values of $\mathrm{BOD}_{5}$ registered on the $\mathrm{CP} 1$ and $\mathrm{CP} 3$. The most pronounced differences in the value of this parameter were registered at the CP1-CP4, CP1-CP2 and CP3-CP4. Based on the stated $\mathrm{BOD}_{5}$ values, according to the defined limit values of this parameter in Serbia, the waters of the Jerma River can be classified as Class I $(<2 \mathrm{mg} / \mathrm{l})$, while the water at other stations would be Class II (2-5 mg/l).

Statistical analysis of suspended solids for all four control points does not show statistically significant differences $\mathrm{p}<0.01(\mathrm{~F}=2.529, \mathrm{p}=0.075)$. The highest level of suspended solids was measured at CP1 $(25.0 \mathrm{mg} / \mathrm{l})$ and the lowest level at CP2 $(12.7 \mathrm{mg} / \mathrm{l})$. The higher levels of suspended solids in the Jerma valley and furthest downstream station are likely a consequence of more intensive erosion processes in the upper part of the Nišava River basin. High turbidity values were also recorded at the CP4 station - 22.9 NTU, which confirms the rule that the higher the concentration of suspended solids the higher the turbidity value. The maximum value of the suspended solids of $367 \mathrm{mg} / \mathrm{l}$ was recorded on May 28, 2012 at the CP4, while a day later the maximum value of $359 \mathrm{mg} / \mathrm{l}$ was recorded in CP1. These are the absolute maximum recorded values of suspended solids in the analyzed 10year period in the Nišava River basin, and they mostly exceeded allowed value for Class II water solvency (max. $25 \mathrm{mg} / \mathrm{l})$. This difference is due to a higher intensity of erosion as a consequence of higher precipitation in 2012 (Djokić 2015).

Statistical analysis of turbidity for all four control points does not show statistically significant differences $\mathrm{p}<0.01(\mathrm{~F}=4.316, \mathrm{p}=0.012)$. The highest values of turbidity were measured at the CP1 (38.6 NTU), while the lowest level was measured at CP2 (10.8 NTU). Maximum mean annual values in the analyzed period were recorded in 2010 at CP1 (46.7 NTU), in 2016 at CP2 (14.2 NTU), in 2015 at CP3 (33.8 NTU) and in 2012 at CP4 (64.95 NTU). Higher mean values of turbidity were recorded in the warmer part of the year, primarily during the spring months, which is a consequence of more intense precipitation that affect the intensity of erosive processes and the increasing number of torrents, especially in the upper part of the basin (Samardžić 2013, Savić 2012). 
Measured values of TON for the research period show significant differences at a significance level $\mathrm{p}<0.01(\mathrm{~F}=8.566, \mathrm{p}=0.0003)$. The highest values of this parameter were measured at $C P 1(1.30 \mathrm{mg} / \mathrm{l})$, while the lowest value was measured at CP4 $(0.61 \mathrm{mg} / \mathrm{l})$. This is confirmed with the post-hoc test, which shows statistically significant differences between these two stations. Apart from between these stations, a statistically significant difference was found between CP1 and CP2. Based on the stated TON values, according to the defined limit values in Serbia, the waters of the Nišava River can be classified as Class I $(<1,5 \mathrm{mg} / \mathrm{l})$. The highest average TON values at CP1 were registered in 2017 and 2018 (1.9 mg/1), at CP2, CP3 and CP4 in 2009 (10 mg/l, $1.1 \mathrm{mg} / \mathrm{l}$ and $0.9 \mathrm{mg} / \mathrm{l})$. The lowest average values of TON were registered in 2010 at CP1 $(0.69 \mathrm{mg} / \mathrm{l})$, in 2015 at CP2 $(0.54 \mathrm{mg} / \mathrm{l})$ and in 2014 at CP3 and CP4 $(0.36 \mathrm{mg} / \mathrm{l}$ and $0.3 \mathrm{mg} / \mathrm{l})$.

Measured values of phosphates for the research period show significant differences at significance level $\mathrm{p}<0.01(\mathrm{~F}=23.508, \mathrm{p}=0.000)$. The highest values of this parameter in the Nišava River basin were recorded at CP1 $(0.281 \mathrm{mg} / \mathrm{l})$, while the lowest value was recorded at CP2 $(0.058 \mathrm{mg} / \mathrm{l})$. This is confirmed with the post-hoc test, which shows statistically significant differences between these two control points. Statistically significant difference was recorded between CP1 and all the others analyzed control points in the basin. Based on the stated values, according to the defined limit values of this parameter in Serbia, the waters of the Nišava River at CP1 can be classified as Class III $(0.2-0.5 \mathrm{mg} / \mathrm{l})$, while the water at other control poins would be Class II $(0.02-0.1 \mathrm{mg} / \mathrm{l})$. The lowest average phosphates values at CP1 were registered in 2009 and 2010 (0.05 mg/l), at CP2 in 2011 $(0.01 \mathrm{mg} / \mathrm{l})$, at CP3 in 2011 and $2012(0.02 \mathrm{mg} / \mathrm{l})$, at CP4 in all years, except 2010 and $2017(0.02 \mathrm{mg} / \mathrm{l})$. The highest average values of phosphates were registered in 2013 at CP1 and CP2 $(0.46 \mathrm{mg} / \mathrm{l}, 0.13 \mathrm{mg} / \mathrm{l})$, in 2015 at CP3 $(0.17 \mathrm{mg} / \mathrm{l})$, in 2012 at CP4 $(0.24 \mathrm{mg} / \mathrm{l})$.

High values of coliform bacteria indicate fecal pollution which mainly originates from untreated municipal waste waters from urban and rural areas, which are discharged directly into the watercourse. Significant presence of coliform bacteria was registered at all the control points, but significant differences are not observed $(\mathrm{F}=3.761, \mathrm{p}=0.020)$ between observed values. The greatest amount of coliform bacteria was registered at CP1 (76 $195 \mathrm{CFU} / \mathrm{l})$, while the smallest was registered at CP4 (5240 CFU/1). Pollution represented by this parameter shows that water quality at all control points belong to Class III. The greatest amount of coliform bacteria, which shows greater water pollution, was registered at CP1 in July 2017, when their amount exceeded 220000 CFU/l (Class IV). Presence of coliform bacteria is an indicator of the highest sanitary contamination of water at CP1.

Independent sample T-test was applied in order to compare arithmetic means of two groups-parameter values in warmer and colder periods of the year. The 
Table 2 - T-test analysis for certain parameters which show water quality in warmer and colder periods in the Nišava River Basin

\begin{tabular}{|c|c|c|c|c|c|}
\hline Parameters & Period of the year & M & $\sigma$ & t-test & $p$ \\
\hline \multirow[t]{2}{*}{ pH } & W & 8.192 & 0.238 & 0.765 & 0.445 \\
\hline & C & 8.179 & 0.230 & & \\
\hline \multirow{2}{*}{$\begin{array}{l}\text { Conductivity } \\
(\mu \mathrm{S} / \mathrm{cm})\end{array}$} & W & 477.259 & 477.259 & 2.761 & $0.006^{*}$ \\
\hline & $C$ & 460.335 & 460.335 & & \\
\hline \multirow{2}{*}{$\begin{array}{l}\mathrm{O}_{2} \text { saturation } \\
(\%)\end{array}$} & W & 97.406 & 16.262 & 0.715 & 0.476 \\
\hline & $C$ & 96.499 & 13.093 & & \\
\hline \multirow{2}{*}{$\begin{array}{l}\mathrm{BOD}_{5} \\
\left(\mathrm{mg} \mathrm{O}_{2} / \mathrm{l}\right)\end{array}$} & W & 2.522 & 0.877 & 0.0006 & 0.999 \\
\hline & $C$ & 2.523 & 1.056 & & \\
\hline \multirow{2}{*}{$\begin{array}{l}\text { Suspended solids } \\
\text { (mg/l) }\end{array}$} & w & 15.739 & 37.482 & -0.711 & 0.477 \\
\hline & $C$ & 17.986 & 28.685 & & \\
\hline \multirow{2}{*}{$\begin{array}{l}\text { Turbidity } \\
\text { (NTU) }\end{array}$} & W & 22.988 & 70.311 & 0.585 & 0.561 \\
\hline & $C$ & 22.396 & 44.256 & & \\
\hline \multirow{2}{*}{$\begin{array}{l}\text { TON } \\
(\mathrm{mg} / \mathrm{l})\end{array}$} & W & 0.928 & 0.566 & 2.169 & $0.031^{* *}$ \\
\hline & C & 0.842 & 0.515 & & \\
\hline \multirow[t]{2}{*}{ Phosphates } & W & 0.121 & 0.185 & -0.014 & 0.998 \\
\hline & $\mathrm{C}$ & 0.122 & 0.204 & & \\
\hline
\end{tabular}

Note: ${ }^{*} \mathrm{p}<0.01 ;{ }^{* *} \mathrm{p}<0.05 ; \mathrm{W}$ - warm period (April-October); C - cold period (October-April) Source: Created by the authors based on data analysis in XIStat Excel

results obtained at all four stations show that particular parameter values are different during warmer and colder periods of the year. During the warmer period, from April to October, values of conductivity are higher at all stations and they mostly belong to I class of water. According to the results of t-test (Table 2) we can state that these differences are statistically significant at a significance level $\mathrm{p}<0.01(\mathrm{t}=2.76, \mathrm{p}=0.006)$. As far as TON parameter is concerned, its values are also higher during spring and summer, which is confirmed by the results of $t$-test at significance level $\mathrm{p}<0.05(\mathrm{t}=2.169, \mathrm{p}=0.031)$. $\mathrm{BOD}_{5}$ and phosphates values are fairly even throughout the year, with a slight increase in the colder period of the year. As far as suspended solids are concerned, their values are higher in the colder period (October-April). The values of $\mathrm{pH}, \mathrm{O}_{2}$ saturation and turbidity are higher during the warm period. However, these differences are small, and they are not statistically significant at a significance level $\mathrm{p}<0.01$ and $\mathrm{p}<0.05$.

Table 3 shows mean SWQI values on annual level and at the level of the seasons for each of the analyzed stations. Annual WQI values show different levels of pollution in the basin, as well as an increase in the level of pollution in the downstream part of the basin. Analysis of water quality by using the WQI indicates that bad water quality was registered on all the profiles on annual basis, with WQI values from 
Table 3 - Mean Annual and Seasonal SWQI in the Nišava basin for the period from 2009 to 2018

\begin{tabular}{lcccc}
\hline & CP1 & CP2 & CP3 & CP4 \\
\hline Spring & 65 & 71 & 72 & 68 \\
Summer & 61 & 68 & 68 & 70 \\
Autumn & 60 & 72 & 68 & 75 \\
Winter & 85 & 89 & 87 & 81 \\
Annual Average & 65 & 69 & 67 & 71 \\
\hline
\end{tabular}

65 (CP1) to 71 (CP4). The Nišava River has water of very good quality (WQI = 85) only during winter, while during all the other seasons the water is of bad quality, with the lowest values during autumn $(\mathrm{WQI}=60)$. At all the other analyzed stations, water quality in winter months ranged from good to very good, while during summer months all the water profiles were of bad quality (WQI = 68-70). In autumn months at CP2 and CP4 the waters reached good quality (WQI = 72-75), while at other control points the trend of bad quality of summer waters continued. The waters of the Nišava River mainly belong to Class III waters (WQI = 39-71).

\section{Discussion}

Based on the applied statistical analysis of water quality parameters, as well as the application of SWQI method, we can conclude that the surface waters of the Nišava River basin in the analyzed 10-year period mainly belong to Class III waters. All the analyzed parameters indicate deterioration of water quality going downstream the course of the Nišava River and reach the most unfavorable results at the lowest downstream station (CP1). This station records the lowest oxygen saturation value $(84.6 \%)$, the highest concentration of suspended solids and turbidity $(25.0 \%$, $38.6 \mathrm{NTU})$, as well as the largest presence of coliform bacteria (76,195 CFU/1). The most significant parameters which indicate an increase in organic pollution in the lower part of the Nišava River course are increased concentrations of $\mathrm{BOD}_{5}$, TON and phosphates.

The results of $\mathrm{BOD}_{5}$ values detected at $\mathrm{CP} 1, \mathrm{CP} 2$ and $\mathrm{CP} 3$ (in the range of 2.1 to $3.3 \mathrm{mg} / \mathrm{l}$ ) indicate the presence of biodegradable organic and classify the water as Class II, while the values at CP4-1,7 mg/l indicate an increase in biological consumption of oxygen and an improvement of water quality level (Class I). In the analyzed period, $\mathrm{BOD}_{5}$ values were slightly increased on all the analyzed profiles. Gvozić et all (2012) reported similar results for the Drava River: mean $B_{0} D_{5}$ values ranged from 2.5 to $2.91 \mathrm{mg} / \mathrm{l}$, respectively, and showed a gradual increase along the river passage downstream. Based on the data from the SEPA (2009-2018), mean $\mathrm{BOD}_{5}$ concentration in Serbian rivers has a slight increase (from $2 \mathrm{mg} / \mathrm{l}$ to 
$2.5 \mathrm{mg} / \mathrm{l})$. In the Sava basin there was an increase in $\mathrm{BOD}_{5}$ value 1.5 to $1.7 \mathrm{mg} / \mathrm{l}$, while in the Morava River basin a decrease in the value of this parameter from 2.8 to $2.6 \mathrm{mg} / \mathrm{l}$ was recorded.

Data from European Environment Agency (2019) indicate that in the period from 1992 to $2017 \mathrm{BOD}_{5}$ values in European rivers decreased by an average of 0.07 $\mathrm{mg} / \mathrm{l}(-2.5 \%$ per year) and in the Danube basin from 3 to $2.6 \mathrm{mg} / \mathrm{l}$.

The average values of TON on the rivers of the Nišava basin were from $0.61 \mathrm{mg} / \mathrm{l}$ (CP4) to $1.30 \mathrm{mg} / \mathrm{l}(\mathrm{CP} 1)$. Increased values of TON indicate pollution of the water body by inadequately purified wastewaters (industry, sewage) and by excessive use of mineral (primarily nitrogen) fertilizers in agricultural production. Greater TON concentrations in the warmer part of the year were recorded on all the stations in the basin. This is affected by reduced discharge on the rivers at this time of the year. Maximum mean TON values in the warmer period of the year were recorded in 2013 at CP1 $(2.8 \mathrm{mg} / \mathrm{l})$, while minimum values were recorded in the cold period in 2010 at CP2 $(0.96 \mathrm{mg} / \mathrm{l})$. The highest average TON values in the Nišava River basin were registered at CP1 in 2017 and $2018-1.9 \mathrm{mg} / \mathrm{l}$, and the lowest mean values in 2014 at CP4 - 0,3 mg/l. Based on this parameter, the waters of the Nišava River basin most often belong to Class I, except in 2013 and 2017, when the values at CP1 were within 1.5-3.0 mg/l (Class II).

Concentration of TON in the Nišava River basin surface water is similar to those obtained in the rivers in eastern Europe, for instance in the Danube and the Sava River (1.6-0.95 and 1.3-1.2 mg/l, respectively; Amić, Tadić 2018). Similar research of Slovenian rivers (Globevnik, Pintar, Bremec 2006) showed that hydro-morphological and chemical pressures from water treatment plants and agglomerations, industrial plants and diffused pollution from agriculture (nitrogen) are the main reasons for the non-attainment of environmental objectives.

Mean annual phosphates values of the Nišava River were from $0.074 \mathrm{mg} / \mathrm{l}$ (CP4) to $0.281 \mathrm{mg} / \mathrm{l}(\mathrm{CP} 1)$. The highest average phosphates values were registered at CP1 in $2013(0.46 \mathrm{mg} / \mathrm{l})$, and the lowest average values in 2014 at CP2 $(0.1 \mathrm{mg} / \mathrm{l})$. The content of phosphates along the Nišava shows a growing trend with a distinct increase in value at $\mathrm{CP}$, primarily due to the impact of wastewater from a large number of farms in this part of the basin, then the impact of wastewater from settlements with unregulated sewage or due to erosion of pollutants from the agricultural areas. SEPA data (2009-2018) indicate that there are no significant changes in the mean phosphate values on the rivers in Serbia, except in the Morava catchment area (to which the Nišava River belongs), where a decrease in the mean concentration has been recorded from 0.12 to $0.08 \mathrm{mg} / \mathrm{l}$. The similar results are observed by Judová and Janský (2005) in rural areas of Czechia (Šlapanka River catchment). The runoff from cultivated farmlands and wastewater from residences without adequate sanitation were identified as the main pollution sources. Ntislidou et al. (2012) in a case study from river basin Kosynthos, in Greece, 
reported levels of phosphates ranging from 0.022 to $0.146 \mathrm{mg} / \mathrm{l}$, respectively. The same study reported TON levels to be in the range of 0.139 to $1.539 \mathrm{mg} / \mathrm{l}$, and BOD ranging from 0.64 to $2.32 \mathrm{mg} / \mathrm{l}$, respectively. The authors linked obtained results with livestock breeding $\left(\mathrm{BOD}_{5}\right.$, nitrates and phosphates), agriculture (nitrates and phosphates) and urban waste waters (nitrates and phosphates). Xu and Zhang (2016) in the study conducted within the upper catchment of Miyun Reservoir in China reported phosphates values ranging from 0.02 to $0.46 \mathrm{mg} / \mathrm{l}$, respectively. The authors found that the phosphates concentrations were positively correlated with the proportion of arable land, grassland, and residential land, and negatively correlated with the forest proportion.

Deterioration in water quality in the Nišava basin along its course from Dimitrovgrad to Niš is confirmed by the obtained results for SWQI. Values of SWQI for research period fluctuate from 56 in 2013 (CP1) to 73 in 2011 (CP4). The first value is classified, according to SWQI descriptive quality indicator as bad (39-71), and the second value can be classified as good (72-83). Along the $151 \mathrm{~km}$ stretch of the Serbian part of the Nišava River, the water quality has dropped modestly, but continuously downstream. The water quality of the Nišava River basin is worse in the warmer period of the year with mean index value of $68(\mathrm{bad})$, while the mean value for the cold period of the year is 77 (good). Numerous researches stated the same trend, e.g. Man-Made Reservoir, Mexico (Rubio Arias et al. 2012), Hebbal Lake, Bangalore, India (Subarsahan, Mahesh, Ramachandra 2019), Veliki Bački Kanal, Serbia (Pantelić et al. 2012), the Drina River (Leščešen et al. 2013), the Sava River (Bjelajac, et al. 2013), the Tisa River (Leščešen et al. 2014; Babić et al. 2019), the Timok River (Brankov, Milijašević, Milanović 2012).

Based on these results, the predominant source of pollution cannot be precisely determined. Surface and ground waters in the Nišava River basin are exposed to the impact of numerous pollutants.

According to the Water management strategy on the territory of the Serbia (Official Gazzete of RS, No. 3/2017), around 75\% of the population of Serbia lives in settlements with more than 2,000 inhabitants, where the average connection to public sewage system is about $72 \%$. In the settlements with less than 2,000 inhabitants, about $5 \%$ of the population is connected to sewage systems. The problem of wastewater, its treatment and discharge into watercourses as the main recipients has not been adequately solved in most of the Nišava basin. According to the data of the SORS (2009-2018), out of the total of 122,498 households on the territory of the Nišava River basin, about $57 \%$ are connected to the water supply network, while $42 \%$ of the households are connected to the sewage network. The problem of wastewater is regulated only in the town of Dimitrovgrad, where household, atmospheric and industrial wastewater is purified. On the territory of the municipality of Pirot a wastewater treatment plant has been operating since 2015 . It currently processes $2 \%$ of the total communal water from the territory of 
the municipality. Downstream from Dimitrovgrad, the Nišava River is burdened by a large amount of wastewater from agricultural areas, as well as communal and industrial waters from Pirot (dairy industry, meat industry, metal and wood processing industry, textile industry rubber factories. In the lower part of the Nišava River communal and most of the industrial wastewater from Niš and the surrounding areas (brewery, dairy, paint and varnish factory, leather processing factory, machine industry) affect water quality the most. They flow into the common sewage network and are discharged into the Nišava downstream from the city (Savić 2012).

\section{Conclusions}

This paper analyzes the state of water quality in the Nišava river basin, through analyzing nine indicators of water quality in a ten-year period. SWQI values show that water quality of the Jerma River is on the border between bad and good (WQI = 71), while all the other profiles register bad water quality. The SWQI value for the CP1 remained in the "bad" range, whereas the water quality of other control points fell into the "good" category. Since 2013 there has been a slight decrease in the water quality on all the profiles. The highest decrease in water quality was recorded at the most downstream station (CP1), where the waters went from good $(\mathrm{WQI}=72)$ to the category of bad (WQI = 69). High levels of coliform bacteria were recorded on all the profiles, as well as increased $\mathrm{BOD}_{5}$, TON and phosphates concentration, which indicates that the waters of the Nišava River and its tributaries are mostly loaded organic compounds originating from the wastewater from the settlements which are discharged into water courses without any treatment. The waters from industrial plant also represents a big problem, but their share in relation to communal water is much lower. Improving the quality of surface water in the Nišava basin lies in the construction of appropriate devices and systems for industrial and municipal water treatment, removal of illegal landfills, improvement and increase of municipal infrastructure capacity (especially in rural areas) and educating the population about the necessity of water protection. If these activities are absent, further deterioration of water quality will result in endangerment of the principle of sustainable use of this renewable natural resource. Since the upper part of the Nišava River is located on the territory of Bulgaria, water quality monitoring should be realized on an international level, with the enactment of adequate strategies and regulations and their implementation. 


\section{References}

AMIĆ, A., TADIĆ, L. (2018): Analysis of Basic Physical-Chemical Parameters, Nutrients and Heavy Metals Content in Surface Water of Small Catchment Area of Karašica and Vučica Rivers in Croatia. Environments, 5, 20, 1-27.

BABIĆ, G., VUKOVIĆ, M., VOZA, D., TAKIĆ, L., MLADENOVIĆ RANISAVLJEVIĆ, I. (2019): Assessing Surface Water Quality in the Serbian Part of the Tisa River Basin. Pol. J. Environ. Stud., 28, 6, 4073-4085.

BHAT, A.S., MERAJ, G., YASEEN, S., PANDIT, A. (2014): Statistical Assessment of Water Quality Parameters for Pollution Source Identification in Sukhnag Stream: An Inflow Stream of Lake Wular (Ramsar Site), Kashmir Himalaya. Journal of Ecosystems Volume 2014, 1-18.

BJELAJAC, D., LEŠČEŠEN, I., MICIĆ, T., PANTELIĆ, D. (2013): Estimation of water quality of Sava River (Vojvodina, Serbia) in the period 2004-2011 using Serbian Water Quality Index (SWQI). Geographica Pannonica, 17, 4, 91-97.

BRANKOV, J., MILIJAŠEVIĆ, D., MILANOVIĆ A. (2012): The assessment of the surface water quality using the water pollution index: a case study of the Timok river (The Danube river basin), Serbia. Archives of environmental protection, 38, 1, 49-61.

BU, H., WAN, J., ZHANG, Y., MENG, W. (2013): Spatial characteristics of surface water quality in the Haicheng River (Liao River basin) in Northeast China. Environ Earth Sci, 70, 2865-2872.

CHOUGULE, B.M., SONAJE, P.N. (2014): Anova method and T-test method as statistical tools for monitoring performance of pilot plant water used in textile wet processing. International Journal of Application or Innovation in Engineering \& Management, 3, 7, 242-248.

CORINE Land Cover database (CLC2012), European Commission.

DAMO, R., ICKA, P. (2013): Evaluation of Water Quality Index for Drinking Water. Pol. J. Environ. Stud., 22, 4,1045-1051.

Directive 2000/60/EC of the European Parliament and of the Council of 23 October 2000 establishing a framework for Community action in the field of water policy (2000). Official Journal of the European Union, L 327, 1-73.

DJOKIĆ, M. (2015): Nišava - potamological study, PhD thesis, Faculty of Sciences and Mathematics, University of Niš.

DRAGIĆEVIĆ, S., NENADOVIĆ, S., JOVANOVIĆ, B., MiLANOViĆ, M., NOVKOVIĆ, I., PAVLOVIĆ, D., LJEŠEVIĆ, M. (2010): Degradation of Topčiderska River water quality (Belgrade). Carpathian Journal of Earth and Environmental Sciences, 5, 2, 177-184.

DUNCA, M.A. (2018): Water Pollution and Water Quality Assessment of Major Transboundary Rivers from Banat (Romania). Journal of Chemistry, 1-9.

European Environment Agency (2019): Oxygen Consuming Substances in European Rivers http://www.eea.europa.eu/ (12.12.2020).

FATHI, E., AHMAD MAHMOODI, Z.R., ZARE BIDAKI, R. (2018): Water quality evaluation using water quality index and multivariate methods, Beheshtabad River, Iran. Applied Water Science, 8, 210, 1-6.

FILIPOVIĆ, I., STRIČEVIĆ, L. (2017): Integral water management on the territory of the town of Kruševac. Collection of works of the Faculty of Geography, University of Belgrade, 65, 1a, 279-294.

GAVRILOVIĆ, L., DUKIĆ, D. (2002): Rivers of Serbia, Institute for textbooks, Belgrade. Geographical atlas. Geozavod 2002, Belgrade.

GOCIĆ, M., TRAJKOVIĆ, S. (2013): Trend analysis of water quality parameters for the Nisava river. Facta universitatis - series: Architecture and Civil Engineering, 11, 3, 199-210. 
GLOBEVNIK, L., PINTAR, M., BREMEC, U. (2006): Cross compliance of the water framework and nitrate directives in Slovenia. Acta Agric. Slov., 87, 69-78.

GVOZDIĆ, V., BRANA, J., MALATESTI, N., ROLAND, D. (2012): Principal component analysis of surface water quality data of the River Drava in eastern Croatia (24year survey). J. Hydroinform. 14, 1051-1060.

HUANG, J., XIANG, W. (2015): Investigation of point source and non-point source pollution for Panjiakou Reservoir in North China by modelling approach. Water Quality Research Journal, $50,2,167-181$.

JOSIMOV DUNDJERSKI, J., SAVIČ, R., GRABIĆ, J., BLAGOJEVIĆ, B. (2016): Water quality of the Danube on the Pannonian part of the course through Serbia. Annals of agronomy,40, $1,8-14$.

JUDOVÁ, P., JANSKÝ, B. (2005): Water quality in rural areas of the Czech Republic: Key study Slapanka River catchment. Limnologica, 35, 160-168.

KUNDU, S. (2012): Application of Statistical Analysis in Assessment of Seasonal and Temporal Variations in Groundwater Quality. Bulletin of Environment, Pharmacology \& Life Sciences, $1,3,7-11$.

LEŠČEŠEN, I., KOTLA, S., OTAŠEVIĆ, K., PANTIĆ, M., JOSIMOV, A., ČEPERKOVIĆ, M. (2013): Assessment of Water Quality Parameters of Drina River (West Serbia) in the Period 2004-2011. European Researcher, 61, 10-2, 2555-2662.

LEŠČEŠEN, I., PANTELIĆ, M., DOLINAJ, D., LUKIĆ, T. (2014): Assessment of water quality of the Tisa River (Vojvodina, North Serbia) for ten year period using Serbian water quality index (SWQI). Geographica Pannonica, 18, 4, 102-107.

LEŠČEŠEN, I., PANTELIĆ, M., DOLINAJ, D., STOJANOVIĆ, V., MILOŠEVIĆ, D. (2015): Statistical analysis of water quality parameters of the Drina river (West Serbia), 2004-2011, Pol. J. Environ. Stud., 24, 2, 555-561.

LEŠČEŠEN, I., PAVIĆ, D., DOLINAJ, D. (2018): Correlation Between Discharge and Water Quality - Case Study Nišava River (Serbia), Geographica Pannonica 22, 2, 97-103.

MACURA, R. (2019): Basics of Statistics, Graphic Publishing Society, Banjaluka.

MARKOVIĆ, P. (2011): Situation and problems in the field of water management at the local level. the Ministry of Agriculture, Forestry and Water Management and the Institute for Water Management “Jaroslav Černi”. Belgrade.

MATIJEVIĆ, B., VASTAG, D.J., BEČELIĆ TOMIN, M., APOSTOLOV, S., DALMACiJA, B. (2014): Multivariate statistical analysis of surface water quality parameters in Vojvodina. Material protection 55, 2,155-162.

MILIJAŠEVIĆ JOKSIMOVIĆ, D., GAVRILOVIĆ, B., OBRADOVIĆ LOVIĆ, S. (2018): Application of the water quality index in the Timok River basin (Serbia). Collection of works of Geography Institute Jovan Cvijić, 68, 3, 333-344.

MUTAVDŽIĆ, B., NIKOLIĆ DJORIĆ, E. (2018): Statistics, Faculty of Agriculture, Novi Sad. NAGEL, J.W. (2001): A water quality index for contact recreation. Water Science and Technology, 43, 285-292.

NAUBI, I., ZARDARI HASSAN, SHIRAZI, M.S., IBRAHIM, B.F.N., BALOO, L. (2016): Effectiveness of Water Quality Index for Monitoring Malaysian River Water Quality. Pol. J. Environ. Stud., 25, 1, 1-9.

NTISLIDOU, CH., BASDEKI, A., PAPACHARALAMPOU, CH., ALBANAKIS, K., LAZARIDOU, M., VOUDOURISV, K. (2012): Ecological Water Quality and Management at a River Basin Kosynthos in June 2011. In: Ecological Water Quality-Water Treatment and Reuse, Chapter 2, Rijeka, Croatia, 23-44. 
Oregon Water Quality Index Summary Report, Water Years 1996-2005, Curtis Cude, DEQ Laboratory Division, Water Quality Monitoring Section, USA.

Official gazette of RS, No. 50/2012. Regulation on Limit Values of Pollutants in Surface and Underground Waters of the Republic of Serbia.

Official Gazzete of RS, No. 3/2017. Water management strategy on the territory of the Republic of Serbia up to 2034 (in Serbian).

PANTELIĆ, M., DOLINAJ, D., SAVIĆ, S., STOJANOVIĆ, V., NADJ, I. (2012): Statistical Analysis of water quality parameters of Veliki Bački Kanal (Vojvodina, Serbia) in period 2000-2009. Carpathian Journal of Earth and Environmental Sciences, 7, 2, 255-264.

PARMAR, K., PARMAR, V. (2010): Evaluation of water quality index for drinking purposes of the river Subernarekha in Singhbhum District. International journal of environmental sciences, 1, 1, 77-81.

PETZ, B. (2007): Basic Statistical Methods for non-mathematicians, Naklada Slap, Zagreb.

PRIYA, S., SAM MANOHAR DAS, S., VAREETHIAH, K. (2016): Analysis of Water Quality in Selected Stations along River Tambaraparani Kanyakumari District, Tamilnadu, India. International Journal of Innovative Science, Engineering and Technology, 3, 8, 319-323.

RUBIO ARIAS, H., CONTRERAS CARAVEO, M., QUINTANA, M.R., SAUCEDO TERAN, R.A., PINALES MUNGUIA, A. (2012): An overall water quality index (WQI) for a man-made aquatic reservoir in Mexico. Int. J Environ Res Public Health, 9,5, 1687.1698.

SAMARDŽIĆ, M. (2013): Temporal and spatial distribution of pollutants in the Velika Morava basin, PhD thesis, University in Novi Sad, Faculty of Agriculture.

SAVIĆ, A. (2012): Ecological analysis of macrozoobenthos communities in the Nišava River, $\mathrm{PhD}$ thesis, Faculty of biology, University of Belgrade.

SEPA (2009-2018): Documentation of Serbian Environmental Protection Agency (SEPA), Quality of waters, 2009-2018, Belgrade.

SIMEONOVA, V., STRATISB, A.J., SAMARAC, C., ZACHARIADISB, G., VOUTSAC, A., ANTHEMIDIS, A., SOFONIOUB, M., KOUIMTZISC, T. (2013): Assessment of the surface water quality in Northern Greece. Water Research, 37, 4119-4124.

SORS (2011): Statistical Office of the Republic of Serbia 2011, http://www.stat.gov.rs (5.12. 2020).

SORS (2009-2018): Statistical Office of the Republic of Serbia, Municipalities and regions 2009-2018, http://www.stat.gov.rs (8.12.2020).

STRIČEVIĆ, L., FILIPOVIĆ, I., RADIVOJEVIĆ, A., MARTIĆ BURSAĆ, N. (2015): Quality analysis of surface waters of Rasina district by using the Water Quality Index method. Serbian Journal of Geosciences, 1, 1, 1-10.

SUBARSAHAN, P., MAHESH, M.K., RAMACHANDRA, T.V. (2019): Assessment of seasonal variation in water quality and water quality index (WQI) of Hebbal lake, Bangalore, India. Environment and ecology, 37, 309-317.

TAKIĆ, L., MLADENOVIĆ-RANISAVLJEVIČ, I., NIKOLIĆ, V., NIKOLIĆ, L., VUKOVIĆ, M., ŽIVKOVIĆ, N. (2012): The assessment of the Danube water quality in Serbia. Advanced technologies, 1, 58-66.

Topographical maps of Niš, 1:200,000, Military Geographical Institute Belgrade.

VADDE, K., WANG, J., CAO, L., YUAN, T., MCCARTHY, A., SEKAR, R. (2018): Assessment of Water Quality and Identification of Pollution Risk Locations in Tiaoxi River (Taihu Watershed) China. Water, 10, 183-201.

VELJKOVIĆ, N. (2006): Indicators of sustainable development and water resource management Zadužbina Andrejević, Belgrade. 
VELJKOVIĆ, N., JOVIČIĆ, M. (2007): Water quality analysis of the Danube in Serbia by the method of Water Quality Index. Waters Protection 07, 49-54.

VELJKOVIĆ, N. (2013): Sustainable development indicators: Case study for South Morava river basin, Hem. Ind. 67, 2, 357-364.

VOROSMARTTY, C.J., MCINTYRE, P.B., GESSNER, M.O., DUDGEON, D., PRUSEVICH, A., GREEN, P., GLIDDEN, S. (2010): Global threats to human water security and river biodiversity. Nature,467, 555-561.

XU, E., ZHANG, H. (2016): Aggregating land use quantity and intensity to link water quality in upper catchment of Miyun Reservoir. Ecol. Indic., 66, 329-339.

YOTOVA, G., VARBANOV, M., TCHERKEZOVA, E., TSAKOVSKI, S. (2020): Water quality assessment of a river catchment by the composite water quality index and self-organizing maps. Ecological indicators, 120, 1-10.

\section{ACKNOWLEDGEMENTS}

The paper shows the results obtained within the Project No. 176008, financed by the Ministry of Education and Science of the Republic of Serbia. The authors would like to acknowledge financial support from the Ministry of Education, Science and Technological Development of the Republic of Serbia (Agreement No 451-03-68/2020-14-200124).

\section{ORCID}

LJILJANA STRIČEVIĆ

https://orcid.org/0000-0002-0574-2009

MILA PAVLOVIĆ

https://orcid.org/0000-0003-4641-8149

IVAN FILIPOVIĆ

https://orcid.org/0000-0003-4687-1314

ALEKSANDAR RADIVOJEVIĆ

https://orcid.org/0000-0002-8176-5165

NATAŠA MARTIĆ BURSAĆ

https://orcid.org/0000-0002-9142-8509

MILENA GOCIĆ

https://orcid.org/0000-0003-1490-0838 